\title{
Continuous vasopressin replacement in diabetes insipidus
}

Charles Ralston, Warwick Butt

Intensive Care Unit, Royal Children's Hospital,

Flemington Road, Parkville,

Victoria,

Australia 3052

Charles Ralston

Warwick Butt

Correspondence to:

Dr Butt.

Accepted 12 March 1990

(Arch DisChild 1990;65:896-7)

\begin{abstract}
Five children who developed diabetes insipidus as a manifestation of severe brain injury received continuous intravenous treatment with a solution containing both aqueous vasopressin and appropriate crystalloid replacement. Polyuria, hypernatraemia, and decreased urine osmolalities were safely corrected in all patients within eight to 28 hours.
\end{abstract}

Diabetes insipidus is a well recognised complication of severe brain injury; its presence indicates damage to the hypothalamoneurohypophyseal axis with associated impairment of vasopressin secretion. The consequent excretion of large volumes of dilute urine can lead to dehydration, hypernatraemia, hypokalaemia, and hypotension if not effectively treated.

This report describes an intravenous replacement regimen utilising aqueous vasopressin and appropriate crystalloid replacement in five children who developed diabetes insipidus during the course of their illness and who were admitted to the intensive care unit.
Patients, methods, and results

The injuries sustained by each patient and the corresponding replacement regimens used are summarised in the table. Vasopressin infusion was given as soon as the diagnosis of diabetes insipidus was confirmed: diagnostic criteria included polyuria $(>30 \mathrm{ml} / \mathrm{kg} /$ day), hypernatraemia, and low urine osmolality $(<250$ $\mathrm{mmol} / \mathrm{kg}$ ). No patient received osmotic diuretics (mannitol) in the 12 hours before, or during the period of, vasopressin infusion. The regimen constituents were dictated by the fluid and electrolyte balance of each patient and administered in conjunction with our standard restricted volume $(10-20 \mathrm{ml} / \mathrm{kg} / 24$ hours) treatment for such cases. Two units of aqueous vasopressin were added to each litre of the appropriate crystalloid solution, and the resultant mixture was infused to replace $80-110 \%$ of measured urine excretion. The volume of replacement was revised according to the previous hour's urinary output. The serum sodium was recorded every two to four hours and the urine osmolality every 12 to 16 hours. The infusion in each case continued until the clinical and biochemical manifestations of diabetes insipidus

Summary of clinical presentation, treatment, and patient outcome

\begin{tabular}{|c|c|c|c|c|c|c|c|c|c|c|c|}
\hline \multirow{3}{*}{$\begin{array}{l}\text { Case } \\
\text { No }\end{array}$} & \multicolumn{3}{|c|}{ Patient details } & \multicolumn{4}{|c|}{ Infusion regimen } & \multicolumn{4}{|l|}{ Results } \\
\hline & \multirow[t]{2}{*}{$\begin{array}{l}\text { Age } \\
\text { (years) }\end{array}$} & \multirow[t]{2}{*}{ Nature of injuries* } & \multirow{2}{*}{$\begin{array}{l}\text { Time of onset } \\
\text { of diabetes } \\
\text { insipidus } \\
\text { (hours) }\end{array}$} & \multirow{2}{*}{$\begin{array}{l}\text { Urine } \\
\text { replaced } \\
(\%)\end{array}$} & \multirow[t]{2}{*}{$\begin{array}{l}\text { Fluid } \\
\text { constitutents }\end{array}$} & \multirow{2}{*}{$\begin{array}{l}\text { Duration } \\
\text { of infusion } \\
\text { (hours) }\end{array}$} & \multirow{2}{*}{$\begin{array}{l}\text { Total dose } \\
\text { of vasopressin } \\
\text { (units) }\end{array}$} & \multicolumn{3}{|c|}{$\begin{array}{l}\text { 'Time to control' of } \\
\text { diabetes insipidus (hours)t }\end{array}$} & \multirow[t]{2}{*}{$\begin{array}{l}\text { Patient } \\
\text { outcome }\end{array}$} \\
\hline & & & & & & & & $\begin{array}{l}\text { Urine } \\
\text { output }\end{array}$ & $\begin{array}{l}\text { Serum } \\
\text { sodium }\end{array}$ & $\begin{array}{l}\text { Urine } \\
\text { osmolality }\end{array}$ & \\
\hline 1 & 8 & $\begin{array}{l}\text { Pedestrian: motor car } \\
\text { accident, closed } \\
\text { head injury and } \\
\text { fractured right } \\
\text { femur, severe } \\
\text { cerebral oedema }\end{array}$ & 6 & 80 & $\begin{array}{l}\text { Half normal saline } \\
+2 \mathrm{U} \text { vasopressin/l }\end{array}$ & 10 & 1.6 & 2 & 6 & 9 & Died \\
\hline 2 & 1.5 & $\begin{array}{l}\text { Pedestrian: motor car } \\
\text { accident, closed } \\
\text { head injury, } \\
\text { cerebral contusions, } \\
\text { subarachnoid blood, } \\
\text { grade III ventricular } \\
\text { haemorrhage }\end{array}$ & 10 & 100 & $\begin{array}{l}\text { (1) Sodium lactate } \\
\text { (Hartmann's solution) } \\
\text { (2) } 5 \% \text { dextrose }+2 U \\
\text { vasopressin/l }\end{array}$ & $\begin{array}{l}\text { (1) } 12 \\
\text { (2) } 36\end{array}$ & $4 \cdot 3$ & 8 & 20 & 28 & $\begin{array}{l}\text { Survived: } \\
\text { full } \\
\text { recovery }\end{array}$ \\
\hline 3 & 6 & $\begin{array}{l}\text { Passenger: motor car, } \\
\text { accident, closed head } \\
\text { injury, mesenteric } \\
\text { lacerations, frontal, } \\
\text { parietal, occipital } \\
\text { haemorrhage, and } \\
\text { cerebral oedema }\end{array}$ & 16 & 110 & $\begin{array}{l}\text { 4\% Dextrose } / 0 \cdot 18 \% \\
\text { saline+2U } \\
\text { vasopressin/l }\end{array}$ & 15 & $5 \cdot 4$ & 8 & 10 & 16 & Died \\
\hline 4 & 15 & $\begin{array}{l}\text { Diabetes mellitus- } \\
\text { ketoacidosis. Day 3: } \\
\text { cerebral oedema }\end{array}$ & 84 & 100 & $\begin{array}{l}5 \% \text { Dextrose }+2 U \\
\text { vasopressin } / 1\end{array}$ & 12 & $6 \cdot 4$ & 8 & 10 & 12 & Died \\
\hline 5 & 14 & $\begin{array}{l}\text { Cyclist: motor car } \\
\text { accident, closed } \\
\text { head injury and } \\
\text { fracture/dislocation } \\
\text { C } 2 / \mathrm{C} 3\end{array}$ & 6 & 100 & $\begin{array}{l}5 \% \text { Dextrose }+40 \mathrm{mmol} \\
\text { potassium chloride }+ \\
2 \mathrm{U} \text { vasopressin/l }\end{array}$ & 8 & $5 \cdot 5$ & 7 & 7 & 7 & Died \\
\hline
\end{tabular}

*Including computed tomogram.

†Defined as: urine output $<2 \mathrm{ml} / \mathrm{kg} / \mathrm{hour}$, serum sodium $<145 \mathrm{mmol} / \mathrm{l}$, and urinary osmolality $>290 \mathrm{mmol} / \mathrm{kg}$. 
had resolved-namely, urine volume $<2$ $\mathrm{ml} / \mathrm{kg} / \mathrm{hr}$, urine osmolality $>300 \mathrm{mmol} / \mathrm{kg}$, and serum sodium concentration $<145 \mathrm{mmol} / \mathrm{l}$.

\section{Discussion}

The clinical course of post-traumatic diabetes insipidus was first elucidated in $1948 .{ }^{1}$ Diagnostic criteria include the excretion of large volumes $(>30 \mathrm{ml} / \mathrm{kg} /$ day) of dilute urine (osmolality $<250 \mathrm{mmol} / \mathrm{kg}$ ) associated with hypernatraemia (serum sodium concentration $>145$ $\mathrm{mmol} / \mathrm{l}$ ) in the absence of concomitant diuretic treatment. ${ }^{2}$ The clinical presentation of diabetes insipidus varies, ${ }^{3}$ but all forms result from inadequate secretion of antidiuretic hormone secondary to disruption of either the supraoptic and paraventricular hypothalamic nucleii, or their neuronal connection to the posterior pituitary gland.

Effective treatment involves the administration of any of a group of synthetic or naturally occurring analogues of antidiuretic hormone by a variety of different methods. ${ }^{4}$ Vasopressin injection (an aqueous solution of the hormone) has a short duration of action (two to eight hours) and is therefore of value in the acute
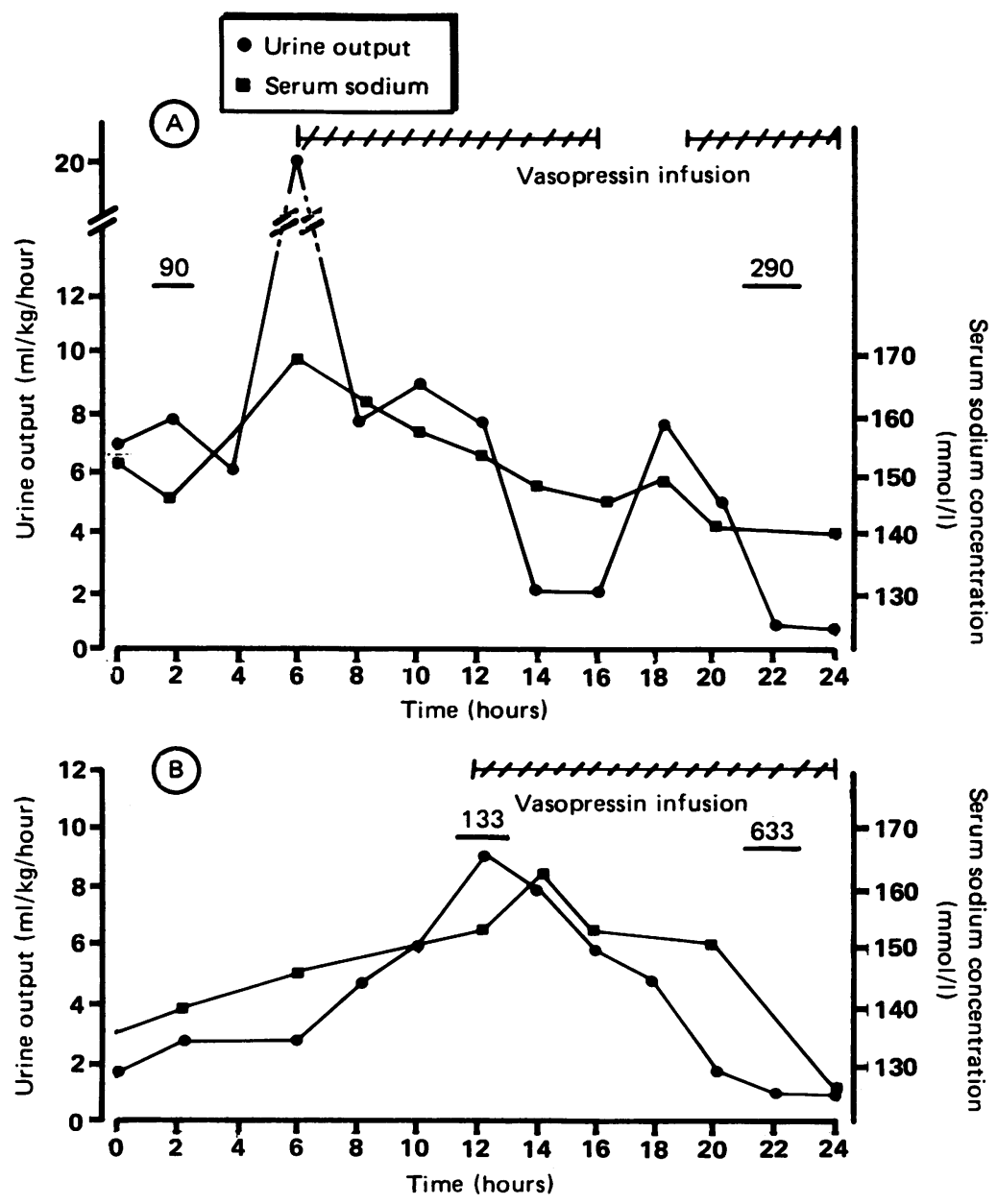

Variation in serum sodium and urine output, both with and without vasopressin replacement for case $3(A)$ and case $4(B)$. Hatched lines indicate the period of vasopressin infusion. underlined numbers represent urinary osmolalities. stages of presentation of diabetes insipidus and its early management. A regimen involving crystalloid replacement of measured hourly urine output, augmented by a small dose ( 2 $\mathrm{U} /$ litre of solution) of aqueous vasopression has been used successfully in adults. We currently use a similar regimen in children.

In all five cases described, the urine output was reduced to acceptable levels within eight hours of diagnosis and treatment of the diabetes insipidus. In each case, however, the serum sodium took an extra six to 20 hours to decrease to $145 \mathrm{mmol} / \mathrm{l}$.

The advantages of this regimen include the steady decrease in the serum sodium concentration, the convenience of administration, its adaptability to changing fluid and electrolyte demands, and an inherent dose regulation corresponding to changing hourly urine production.

This flexibility is illustrated in case 3 (figure A). Cessation of the infusion at 15 hours coincided with unmasking of persistent diabetes insipidus, while resumption of the replacement regimen brought resolution of symptoms in a further six hours. A possible disadvantage (common to all therapeutic alternatives) is the danger of vasopressin overdosage and associated water toxicity; in case 4 (figure B), the serum sodium concentration fell to $127 \mathrm{mmol} / 1$ and was associated with a high urinary osmolality and a urine output of $1 \mathrm{ml} / \mathrm{kg} /$ hour. Water overload and cerebral oedema are potential hazards of this treatment; thus the patient's conscious state must be frequently monitored and the intracranial pressure measured if the patient is receiving muscle paralysing drugs. Frequent biochemical testing (measurement of urine volume every hour, electrolytes every four hours, and urine osmolalities every 12 hours) is also essential. Overall, the average dose of vasopressin administered was $9 \mathrm{mU} / \mathrm{kg} /$ hour (range $5-14 \mathrm{mU} / \mathrm{kg} /$ hour). This is significantly greater than the intravenous regimen described by Chanson et $a l^{5}$ but compares favourably with other proposed regimens. ${ }^{6}$

This report describes an effective, safe, and convenient method of administration of vasopressin and crystalloid replacement that optimises the physiological state of a head injured patient who has diabetes insipidus. It is likely that this regimen could also be used in children with diabetes insipidus after neurosurgery.

This regimen was introduced to the intensive care unit by $\mathrm{Dr}$ Frank Shann.

Porter RJ, Miller RA. Diabetes insipidus following closed head injury. 7 Neurol Neurosurg Psychiatry 1948;2:258-62. Roberton GL. Diseases of posterior pituitary. Clin Endocrinol Metab 1981;10:251-77.

Defoer F, Mahler C, Dua G, Appel B. Post-traumatic diabetes insipidus. Acta Anaesthesiol (Belg) 1987;38:397-99. tes insipidus. Acra Anaesthesiol (Belg) tes insipidus. F Neurosurg Nurs 1988;20:58-9.

Ces insipidus. F Neurosurg Nurs 1988;20:58-9. Ultra-low dhanson P, Jedynak CP, Dabrowsk G, et al. Ultra-low doses vasopressin in the treatment of diabetes insipidus.
Crit Care Med 1987;15:44-6. 6 Edwards CRW. Vasopressin analogues in the treatment of diabetes insipidus: clinical and laboratory studies. $\mathrm{Br} M e d \mathcal{F}$ diabetes insipidus: 